\title{
The moderating role of personal culture on the relationship between retail brand personality and shoppers' loyalty: An evidence of supermarkets in Vietnam
}

\author{
Nguyen Le Thai Hoa
}

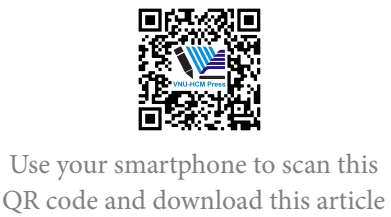

\begin{abstract}
Nowadays, one of the most common trends in retail industry research is the attribution of human characteristics or traits to retail brands. The term "retail brand personality or retailer personality" was born with various definitions and measurement scales from different cultures. Therefore, this paper aims are (i) to develop retail brand personality measurement scale tailor-made for general supermarkets, the most popular retail format in Vietnam, (ii) to measure the impact of retail brand personality dimensions on shoppers' loyalty, and (iii) to investigate the moderating effects of personal cultural orientations on these relationships. The scale was developed through two stages: Item generation and item purification with the collected data on quota sampling of 403 shoppinggoers, and then analyzed by SEM and MSEM method (Moderated structural equation modeling). The results indicated that retail brand personality consisted of four dimensions: Reliability, Sophistication, Modern, and Family-oriented, significantly found to impact on shoppers' loyalty, in which Sophistication and Reliability were the strongest. More interestingly, the moderating role of personal cultural orientations in these regards was greatly identified. Particularly, shoppers with high independence culture highly appreciated the relationship between Sophistication and Modern dimensions and shoppers' loyalty whereas shoppers with high Interdependence culture only supported for the impact of Reliability on loyalty. However, both personal culture orientations were found not be significantly related directly to the loyalty. The findings may help retailers and marketers come up with more effective marketing solutions in terms of enhancing symbolic values for their retail brands and adjust their integrated marketing and communication activities accordingly. This paper has a significant contribution of exploring the moderating role of personal cultural orientations on the relationship between retail brand personality and shoppers' loyalty by the new analysis methodology - MSEM.
\end{abstract}

Key words: Brand personality, culture, loyalty, moderator, retail, Vietnam

Saigon Technology University (STU), Ho Chi Minh City, Vietnam.

Email: hoamai54@yahoo.com

History

- Received: 8/4/2019

- Accepted: $29 / 5 / 2019$

- Published: 31/12/2019

DOI :10.32508/stdjelm.v3i4.574

\section{Check for updates}

\section{Copyright}

(c) VNU-HCM Press. This is an openaccess article distributed under the terms of the Creative Commons Attribution 4.0 International license.

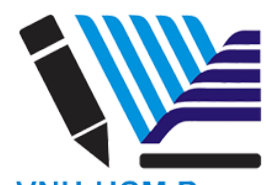

VNU-HCM Press

\section{INTRODUCTION}

With the population of more than 100 million, retail market in Vietnam is very potential but the competition is also strong with the advent of new retail formats, together with the arrival of giant foreign retailers ${ }^{1}$. Therefore, shoppers have more choices than before, as a result shoppers' loyalty is gradually decreasing ${ }^{2}$. According to Floor (2006): “To survive in the current tough retail environment and to create sustainable development, retailers must have effective strategies to differentiate themselves from rival, achieve customers' loyalty, and gain long-term benefits" ${ }^{3}$.Therefore, retail ers should build an outstanding brand for themselves in shoppers' mind as retail differentiation cannot be achieved without branding. The symbolic benefit of using brands come from the image of brand ambassadors and/or the brand personality itself ${ }^{4}$.
Nowadays, branding and brand management are not only applied for product brands, but also for retail brands ${ }^{5}$. In retail branding research, human personality characteristics or traits are often attributed to retail brand s due to its important role in perceived differentiation, satisfaction, patronage, attachment, and loyalty behavior ${ }^{6-10}$. In general, retail brand personality influences consumers' behavior: trust ${ }^{11-13}$, attachment $^{11,12}$, commitment ${ }^{12}$, satisfaction ${ }^{14}$, attitude ${ }^{4,12,13}$, and shopping value and patronage intension $^{15}$. Additionally, in online shopping, website personality was found to influence positively on utilitarian, hedonic web browsing and online impulse buying ${ }^{16}$. By creating symbolic representation, retail brand personality is also an sustainable competitive advantage for retailers since it is a powerful tool to position and differentiate a retailer from its competitors ${ }^{17}$. Furthermore, consumers are likely to choose brands whose personalities match their own ${ }^{3,18}$, to 
simplify their buying decisions in the situations of uncertainty ${ }^{19}$ and to select retailers for shopping when quality, price and service are similar ${ }^{20}$. Several previous research indicated that retail brand personality contributed to the overall store image, helped to obtain positioning goals, and enhanced loyalty, purchase intentions, sales and profitability ${ }^{21}$. However, most of the studies have been conducted in United States or European countries, there is the lack of studies in Asia, where the culture is totally different.

Retail brand personality may be changed from format to format and from culture to culture ${ }^{22,23}$ as a result, some measurement scales have been developed in different contexts ${ }^{4,24-27}$. However, the existing scales could not be used for this study. Therefore, the first purpose of this paper is to develop retail brand personality scale tailor-made for supermarkets, the most popular retail format in Vietnam. Secondly, though previous studies confirmed the positive relationship between product brand personality and customer loyalty, the research on the influence of retail brand personality on shoppers' loyalty has been just explored in recent time ${ }^{8,28,29}$. The second objective is to make effort to investigate this relationship in a new research context. Lastly, the impact of culture moderates the relationships has not been discovered in previous research yet. Straughan and Albert-Miller (2001) argued that there were two reasons for retailers to be aware of cultures. First, domestic markets in some countries were becoming more culturally diverse. As a result, retailers would be able to use cultural themes as a means for market segmentation and targeting customers. Second, the saturation of domestic market forced retailers to expand to international markets. Culture would become the challenge for multinational retailers to overcome ${ }^{30}$. Therefore, this paper aims to fulfill this research gap, particularly, to explore the moderating effects of personal culture on these relationships.

The findings of this study verified the relationship between retail brand personality with customers' loyalty towards store and discovered the moderating role of culture that previous studies have been neglected. The remainder of the paper is structured as follows with literature review, proposed research model, methodology, data analysis, theoretical and practical implications and recommendations for future research.

\section{LITERATURE REVIEW}

\section{Retail brand (store) personality}

A retail brand was defined as "a group of the retailers' outlets which carry a unique name, symbol, logo or combination thereof " by Zentes et al (2008, p.167) ${ }^{8}$. Ailawadi and Keller (2004, p. 332) argued that: "A retail brand identifies the goods and services of a retailer and differentiates them from those of competitors" ${ }^{5}$. In the field of personality studies, the personality trait theory is one of the most critically debated. Allport (1897) was one of the pioneers of formal personality psychology and came up with 4,000 words describing human personality in three main categories: cardinal traits, central traits, and secondary traits. Next, Cattell narrowed down this list by factor analysis into 16 personality factors including warmth, reasoning, emotional stability, dominance, liveliness, rule-consciousness, social boldness, sensitivity, vigilance, abstractness, privateness, apprehension, openness to change, self-reliance, perfectionism, and tension. Eysenck (1916) continued to reduce the 16PFs into three dimensions: IntroversionExtraversion, Neuroticism-Emotional Stability, and Psychoticism. Finally, the Big Five theory was formulated with 5 core traits: Extraversion, Openness to Experience, Agreeableness, Cons cientiousness, and Neuroticism.

General definition of retail brand personality started from the concept of brand personality in marketing literature, defined by Aaker (1997, p. 347) as " a set of human characteristics associated with a brand" 31 . Actually, this concept was firstly identified by Martineau (1958), defined as " the way in which store is defined in the shopper's mind partly by its functional qualities and partly an aura of psychological attributes" 20 . However, four store personality dimensions in Martineau 's seminal article namely, layout and architecture, symbo ls and colors, advertising and sales personnel were actually considered the concept of functional store image. Thus, d'Atous and Leveque (2003, p. 456-457) distinguished store personality from store image when they argued that: "Whereas store image is mental representation that encompasses all dimensions that are associated with a store (value for money, product selection, quality of service, ect.), store personality is restricted to those mental dimensions that correspond to human traits ". For instance, product quality is an important attribute of an overall store image but it is clearly not a personality trait ${ }^{24}$. Recently, Das et al (2012b) in their research of department store indicated that store personality was a consumer's perception of the human personality traits attributed to a store $^{8}$.

Retail brand personality is a multi-dimensional construct and each different research context has different store personality dimensions ${ }^{4,8,24,25,27}$. Normally, product brand personality referred to all positive dimensions ${ }^{31}$ whereas retailer personality was 
also mentioned into some negative ones such as unpleasantness $^{24}$, deceitfulness ${ }^{32}$, Informality, Ruthlessness ${ }^{33}$ and $\operatorname{chaos}^{25}$. Due to the specific criteria of culture and format, this paper has developed the measurement scale of retail brand personality tailoring for supermarkets in Vietnam. This newly-developed scale structure is also multidimensional, including four dimensions: Reliability, Sophistication, Modern, and Family-oriented, close to the specialty store personality from Hoa and Thao (2017b) (See part Retail brand personality measurement scale development).

\section{Customer loyalty}

As a key to organizational success and profitability, c ustomer loyalty could be classified into brand loyalty, vendor loyalty, service loyalty, and store loyalty ${ }^{34}$. Retail brand/store loyalty is defined as "the tendency to be loyal to a focal retailer as demonstrated by the intention to buy from the retailer as a primary choice " (Pappu and Quester, 2006, p. 320) ${ }^{35}$.

Loyalty is considered in two different points of view: Attitudinal and behavioral. Attitudinal loyalty is preference or psychological commitment, and more particularly, favorable attitude to the specified retailer, and operationally it can be measured future probability of purchase. Behavioral loyalty focuses on observing and measuring the continuation of purchases in the past, namely purchasing history, probability of purchase of the same product, or time for a specific brand $^{36}$. This research applied the framework developed by Dick and Basu (1994) who combined both attitudinal and behavioral measures. In other words, loyalty is determined by a combination of repeat purchase levels and relative attitude ${ }^{37}$.

\section{The impact of retail brand personality on shoppers' loyalty}

Retail brand personality positions target customers, enhances shoppers ' loyalty, and creates retail sales and profitability ${ }^{21}$. With the regard of the relationship between retail brand personality and loyalty, Merrilees and Miller (2002) only found the "Sincerity" dimension to have direct influence on shoppers' loyalty without mentioning the other four dimensions ${ }^{38}$. Zentes et al (2008) applied the general brand personality scale of Aaker (1997) and demonstrated the direct impact of retail brand personality on shoppers' loyalty in German different retail sectors such as food, furniture, books, beauty and health care, clothing, consumer electronics. Subsequently, Lombart and Louis (2012a) empirically showed that customer satisfaction and loyalty were two important consequences of retail bra nd personality ${ }^{14}$. In 2014, with partial least squares analysis (PLS), these two authors also asserted that CSR and price image impacted significantly on retailer personality, and retailer personality had influence on satisfaction, trust and loyalty towards retailers (measured by their attitude and future behavioral intentions) in French grocery retail context ${ }^{39}$. However, in shopping mall context, Kim et al (2015) verified that brand personality just had direct influence on satisfaction but indirectly on loyalty. Recently, Das et al (2014b), Hoa and Thao (2017a,b) also indicated that department /specialty store personality positively affected on shoppers' loyalty. However, they only considered the construct "retailer personality" as a single dimensional construct. In this study, the following hypothesis is proposed for supermarket personality with four recently developed dimensions: Hypothesis 1: Retail brand dimensions, including Reliability (H1a), Sophistication (H1b), Modern (H1c), and Family-oriented (H1d) influence positively on shoppers' loyalty.

\section{Culture and its moderating role on the re- lationship between retail brand personality and shoppers' loyalty}

Culture is likely to play an increasingly important role in determining the success/failure of international retailers. Hofstede (1991, p.5) defined culture as "collective programming of the mind which distinguishes the members of one group or category of people from those of another" ${ }^{40}$. Additionally, Hong et al (2000) asserted that "Culture represents a set of shared knowledge and implicit theories about the world, including beliefs, values, attitudes, and other constructs needed to interpret and navigate various environments". It is agreed that each culture has its own cultural traditions, which are deeply ingrained in their social norms and values, and thus have strong effects on their attitudes and behaviors. Hofstede (1991) identified five dimensions of national culture: Individualism/Collectivism; high/low uncertainty avoidance; masculinity/femininity; high/low power distance and long/short term orientations. Among five cultural dimensions, individualism-collectivism has been used by most researchers to explore difference in consumer behavior across several countries ${ }^{30,41}$.

However, Hofstede's nation-level cultural dimensions have been criticized for studies on cross-cultural differences at individual level in consumer behavior, because all the citizens of a country may not share similar cultural characteristics. For instance, European Americans are not necessarily more individualistic than African Americans or Latin Americans, 
and not less collectivistic than Japanese or Korean ${ }^{42}$. According to Schwartz (1994), most societies have at least some representation of both individualistic and collectivistic worldviews, and they deal with the individual and collective-oriented value choices separately. The present study analyzed two dimensions of personal cultural orientations developed by Sharma (2010): Independence/interdependence. These two negatively related constructs are considered to address a major limitation of Hofstede's conceptualization of individualism and collectivism as the two ends of continuum since both these tendencies may coexist in all individuals and all societies ${ }^{43}$.

\section{Independence/interdependence}

Sharma (2010, p.790) defined "Independence as a personal cultural orientation associated with acting independently, a strong self-concept, a sense of freedom, autonomy, and personal achievement; and Interdependence as a personal cultural orientations associated with acting as a part of one or more in-groups, a strong group identity, a sense of belongingness, reliance on others, giving importance to group-goals over own individual goals and collective achievement".

\section{The moderating role of indepen- dence/interdependence}

In collectivism culture, the need, value and goal of the group take precedence over those of the individual. High level of collectivism will foster greater communication, cooperation, and harmony within society. Customers in collectivism culture are less demanding than their individualist counterparts, who want prompt and accurate service ${ }^{44}$. Consumers with strong collectivist value are more trusting of in-group members than of out-group members ${ }^{45}$.

Additionally, It was stated that persons with high collectivistic characteristics tended to stick to the brands/stores they chosen. Therefore, the collectivist notion of interdependence with the in-group would seem to enhance loyalty tendency ${ }^{41}$. These are contradictory to the previous findings by Lam (2007), that persons with high-scored individualism were more prone to brand loyalty than those who scored low because they tended to stick to their adopted brands regardless of outside influence. Lam (2007) also revealed that persons with high collectivistic characteristics were more likely to switch brands frequently because they wanted to follow behavior of their in-group members ${ }^{46}$.

In this paper, two personal culture orientations (Independence and Interdependence) are hypothesized as mixed moderators. They are independent variables impacting directly on customer loyalty as well as moderate on the relationship between retailer personality and loyalty. Therefore, the following hypotheses are proposed:

Hypothesis 2: Independent has a positive impact on the relationship between retail brand personality dimensions: reliability (H2a), sophistication ( $\mathrm{H} 2 b)$, familyoriented (H2c), and modern (H2d) and shoppers' loyalty.

Hypothesis 3: Interdependent has a negative impact on the relationship between retail brand personality dimensions, reliability (H3a), sophistication (H3b), family-oriented (H3c), and modern (H3d) and shoppers' loyalty.

\section{RESEARCH METHODOLOGY}

\section{Research design}

In order to fulfill the research objectives, both qualitative and quantitative methods were used to collect primary data. In the qualitative research, 10 in-depth interviews were conducted with semistructured questions to develop the scale of retail brand personality, re-evaluate the measurement scale of loyalty, Independence and Interdependence, and explore the influence of personality or independence/interdependence in personal culture on customer loyalty. The qualitative results showed that one of five indicators in Independence scale of Sharma (2010) was omitted since it expressed the same meaning with another according to Vietnamese context. Independence scale remained with 4 indicators. Based on this result and existing literature, the final questionnaire was designed for the survey. Collected data was analyzed with EFA (exploratory factor analysis) and Cronbach's alpha by the software IBM SPSS Statistics 22.0 and CFA (confirmed factor analysis), SEM (structural equation model) and MSEM (moderated structural equation model) by IBM SPSS AMOS 6.0.

\section{Sampling}

The survey was carried out with 403 shoppers in Vietnam on the purpose of investigating the impact of four new dimensions of retail brand personality on customer loyalty and the moderating role of Independence and Interdependence on these relationships. Nonprobability sampling method was chosen with quota sampling from five top supermarket chains in Vietnam, namely, Coopmart, Big C, Lottemart, Vinmart and Aeon in three big cities in Vietnam including Ha Noi, Ho Chi Minh, and Da Nang at different time 
slots of the day, weekdays and weekends to avoid periodicity and non-coverage problems ${ }^{47}$. The author also participated the survey by assisting and supervising interviewers. The sample was collected with the range of ages from 18 to 60 , of which the age between 30 and 45 accounted for $45.8 \%$. Females occupied $70.6 \%$ compared with $29,4 \%$ of males. $27.8 \%$ of respondents were undergraduate with monthly income of more than 10 million Vietnam dongs (US\$ 450).

\section{Retail brand personality measurement scale development}

The scale development process for retail brand personality in case of supermarkets was done in two stages: Item generation and purification.

\section{Item generation}

The first list of retail brand personality was collected from existing scales including, Aaker (1997), d'Atous and Levesque (2003), Helgeson and Supphellen (2004), Davies et al (2004), Louis and Lombart (2011, 2014),Willems et al (2011) and Das et al $(2012 b)^{48}$.

After deleting the synonym items from the list of human characteristics in the above scales, the extensive list remains 94 items. Next, 20 interviews $(5$ men and 15 women, age range: 20-50 in Ho Chi Minh City) were conducted to validate this 94 items and to encourage the respondents to give out more relevant adjectives describing supermarket s' characteristics. In the interviews, we firstly introduced the concept of retail brand personality and showed the list of 94 human traits. By using triadic sorting method (showing one set of three supermarkets), respondents were requested to select some important personality traits from these three supermarkets if they expected to go shopping there and to point out which items were similar in two supermarkets and different from others. Data saturation point was obtained when respondents could not find out any new characteristics. 6 more characteristics were added to the list, namely, indifferent, economical, virtuous, loyal, family-caring, and chastity. Subsequently, the preliminary reduction stage was carried out. Twenty shoppers were required to rate these 100 items with 7 point interval scale (1: very uncharacteristic and 7 : completely characteristic). With three criteria set by Willems et al (2011) : The items must get minimum point rating of 4 , the item should be rated by at least $25 \%$ of respondents and they must be suitable for human beings, the result of this analysis remained only 22 personality items for next purification.

\section{Item purification}

The item purification was conducted through the general survey in this research (see section 3.2: Sampling). Similarly, the respondents must choose one among five above - mentioned supermarkets and attribute it with 22 personality traits by rating 5 - point interval scale. After that, exploratory factor analysis (EFA) was processed to extract dimensions and purify the items by using principal component analysis (PCA) and varimax rotations with SPSS version 22. Based on two standards from Nunnally $(1994)^{49}$, loading factors must be higher than 0.50 and the gap between two loadings is above 0.3 , four item s were eliminated. The EFA result indicated that $\mathrm{f}$ our $-\mathrm{fac}-$ tor structure was formed with the Eigenvalues of each factor was 1,$889 ; 2.309 ; 3.633$; and 4.156 (greater than one) and cumulative variance explaining $66.593 \%$. This structure was also meaningful, interpretable and renamed with 18 items as follows : Reliability (5 items), sophistication (5 items), modern (4 items) and family-oriented (4 items). Cronbach's alpha coefficients were then analyzed with two items more was eliminated from Reliability and Sophistication. The new Cronbach's alpha was 0.825 for Reliability, 0.8 52 for Sophistication, 0.886 for Family-oriented and 0.897 for Modern, higher than 0.70 that met the minimum statistics requirement ${ }^{49}$. The scale remains 16 items for four dimensions.

Next, confirmatory factor analysis (CFA) was run to reconfirm the above result by AMOS software (Version 22). The results indicated the good model fit with Chi-square $=263.886$, degrees of freedom $=98$, probability level $=0.000, \mathrm{CMIN} / \mathrm{df}=2.693$ ( within 2 and 5), $\mathrm{GFI}=0.922$, CFI $=0.951$, TLI $=0.940$ (Greater than 0.9 ), Hoelter $=205$ and RMSEA $=0.065$ (smaller than $0.08)^{50}$. All loading factors were higher than 0.50 and satisfied convergent validity. Then, the final list of supermarket personality in Vietnam was identified including 16 items in four dimensions.

\section{Measurement scale}

The questionnaire was composed in English and then translated into Vietnamese with two parts: Part 1 included 29 items to measure seven latent variables by five-point likert scale and part 2 was personal data of respondents. Beside four newly developed personality dimensions, the measuring items were adapted from previous studies: Customer loyalty toward supermarkets from Pappu and Quester $(2006)^{51}$, and independence/interdependence from Sharma (2010). 


\section{DATA ANALYSIS \& FINDINGS}

\section{Measurement model}

EFA and Cronbach Alpha analysis was run to test the reliability, convergent validity, and discriminant validity of customer loyalty and two personal cultural orientations and the results indicated that three variables met the requirements.

The full measurement model which was constructed including 29 items as indicator variables, and 7 constructs as latent variables, was analyzed by performing CFA. After deleting two indicators SOP03 (standard regression weight $=0.496$ ) and IND03 (Modification index was too high), the results revealed a good model fit: Chi-square $=464.627$; degrees of freedom $=$ 303; probability level $=0.000$; and $\mathrm{CMIN} / \mathrm{DF}=1.533$. Other fit statistics were AGFI $=0.901, \mathrm{GFI}=0.920$, $\mathrm{CFI}=0.976, \mathrm{TLI}=0.979, \mathrm{RMSEA}=0.036(<0.08)$, $\mathrm{NFI}=0.943$, Hoelter $=300(>200)$. All t-test of the indicator variables were significant at the 0.001 level and all standardized regression weights were greater than 0.50 (See Figure 1). Thus, all the constructs meet convergent validity. Correlation estimates among these constructs were also significant at 0.001 level with $\mathrm{r} \neq$ 1 and the discriminant validity was then obtained (see Table 1). Additionally, composite reliability $\rho_{c}$ and average variance extracted $\rho_{v c}$ were also tested with the formulations from Jöreskog (1971, p. 111) ${ }^{\mathrm{a}} 52$. The Table 2 showed that seven latent variables meet the requirements of composite reliability (above 0.70 ) and average variance extracted (above 0.50).

\section{Structural model with MSEM (Moderated structural equation model)}

Normally, to test the impact of moderators on the relationship between two constructs, multi-group analysis (MGA) is used in most of research. However, MGA is only used for discret variables or qualitative variables such as age, gender or income. In this paper, structural model has two moderators (independence and interdependence) as continuous/quantitative variables. If common MGA is employed, these two continuous variables must be transformed into categorical variable s by median split or quartile split. However, in this process, the data may be missing ${ }^{53}$, and the results may appear nonlinear and nonrandom measurement errors ${ }^{54}$.

Therefore, MSEM approach is used instead of multigroup analysis - MGA in case the moderators are continuous/quantitative variable to avoid this problem.

\footnotetext{
${ }^{\mathrm{a}} \rho_{\mathrm{c}}=\frac{\left(\sum_{i=1}^{p} \lambda_{i}\right)^{2}}{\left(\sum_{i=1}^{p} \lambda_{i}\right)^{2}+\sum_{i=1}^{p}\left(1-\lambda_{i}^{2}\right)}$ and $\rho_{\mathrm{vc}}=\frac{\sum_{i=1}^{p} \lambda \mathbf{i}^{2}}{\sum_{i=1}^{p} \lambda \mathbf{i}^{2}+\sum_{i=1}^{p}\left(1-\lambda \mathbf{i}^{2}\right)}$ In which, $\lambda \mathrm{i}$ : standardised estimates of regression weights, $i$.. p: the
} number of indicators.
Besides, MSEM allows to evaluate and adjust measurement errors ${ }^{55}$ (Bakker and Demerouti, 2009). MSEM analysis was based on the process of Ping $(1995)^{56}$ by calculating interaction effect. To avoid the multicollinearity, the mean deviated or mean centered variable was used ${ }^{57,58}$. Using EXCEL software to convert a random variable into mean centered variable by taking average of its centered indicators in which centered indicators was calculated by the subtraction between themselves and sample mean. Two MSEM models for two moderators (Independence and Interdependence) were analyzed with a generalized regression equation as follows:

$$
\mathrm{SL}=\beta_{0}+\beta_{1} \mathrm{RP}+\beta_{2} \mathrm{IC}+\gamma \mathrm{SP}^{\star} \mathrm{PC}+\xi
$$

In which SL: shoppers' loyalty, R P: Retailer personality, P C: Personal culture, $\mathrm{RP}^{\star} \mathrm{P} \mathrm{C}$ : interaction effect of R P and P C, $\beta_{0,} \beta_{1} \beta_{2}, \gamma$ : structural coefficients, $\xi$ : structural disturbance.

The results of the structural model with Independence moderator indicated that it also achieved an acceptable level of fit: Chi-square $=582.225, \mathrm{df}=288 ; \mathrm{p}=$ $0.000 ; \mathrm{CMIN} / \mathrm{df}=2.022 ; \mathrm{GFI}=0.901 ; \mathrm{AGFI}=0.880$, $\mathrm{TLI}=0.935 ; \mathrm{CFI}=0.942$, RMSEA $=0.050 ; \mathrm{NFI}=$ 0.892 , Hoelter $=228$. SMC (Squared multi correlations) for store loyalty was 0.304 , which meant that four store personality dimensions could explain 30.4 $\%$ for shoppers' loyalty (See Figure 2). Sophistication and Reliability positively influenced shoppers ' loyalty at the signif icant level of 5\% whereas Family-oriented and Modern positively impacted shoppers' loyalty at the significant level of $10 \%$. In addition, among the four moderated hypotheses, the two interaction effect of Sophistication and Modern with Independence was significant with the estimate equal to -.059 and .078 . It means that Independence decreases the degree of influence of Sophistication and increases the degree of influence of Modern on loyalty (See Table 3).

Next, the results of the structural model with Interdependence moderator also indicated an acceptable level of fit: Chi-square $=600.119, \mathrm{df}=339 ; \mathrm{p}=.000$; $\mathrm{CMIN} / \mathrm{df}=1.770 ; \mathrm{GFI}=.906 ; \mathrm{AGFI}=0.887, \mathrm{TLI}=$ .956; CFI $=.961$, RMSEA $=.044 ; \mathrm{NFI}=0.915$, Hoelter $=258$. SMC (Squared multi correlations) for customer loyalty was 0.258 , which meant that four retail brand personality dimensions could explain $25.8 \%$ for shoppers' loyalty (See Figure 3). Sophistication, Reliability and Modern positively influenced shoppers ' loyalty at the significant level of 5\% and Familyoriented had statistically significant impact on loyalty at the significant level of $10 \%$. Additionally, among four moderated hypotheses, only one hypotheses of 
Table 1: The results of correlation among research constructs

\begin{tabular}{|c|c|c|c|c|c|}
\hline Relationship & $\mathbf{r}$ & $\begin{array}{c}\mathrm{SE}=\operatorname{SQRT}((1- \\
\mathrm{r} 2) /(\mathrm{n}-2))\end{array}$ & 1-r & $\mathrm{CR}=(1-\mathrm{r}) / \mathrm{SE}$ & P-VALUE \\
\hline REL $<->$ SOP & 0.148 & 0.049 & 0.852 & 17.465 & 0.000 \\
\hline $\mathrm{REL}<->\mathrm{MOD}$ & -0.108 & 0.049 & 1.108 & 22.595 & 0.000 \\
\hline REL $<->$ FAM & -0.2 & 0.048 & 1.200 & 24.829 & 0.000 \\
\hline SOP $<->$ MOD & 0.337 & 0.046 & 0.663 & 14.276 & 0.000 \\
\hline SOP $<->$ FAM & 0.011 & 0.049 & 0.989 & 20.051 & 0.000 \\
\hline MOD $<->$ FAM & 0.41 & 0.045 & 0.590 & 13.114 & 0.000 \\
\hline REL $<->$ LOY & 0.309 & 0.047 & 0.691 & 14.730 & 0.000 \\
\hline REL $<->$ IND & -0.194 & 0.048 & 1.194 & 24.675 & 0.000 \\
\hline REL $<->$ INT & 0.103 & 0.049 & 0.897 & 18.282 & 0.000 \\
\hline SOP $<->$ LOY & 0.431 & 0.045 & 0.569 & 12.784 & 0.000 \\
\hline SOP $<->$ IND & 0.122 & 0.049 & 0.878 & 17.934 & 0.000 \\
\hline $\mathrm{SOP}<->\mathrm{INT}$ & -0.051 & 0.049 & 1.051 & 21.335 & 0.000 \\
\hline MOD $<->$ LOY & 0.249 & 0.048 & 0.751 & 15.720 & 0.000 \\
\hline $\mathrm{MOD}<->$ IND & 0.118 & 0.049 & 0.882 & 18.007 & 0.000 \\
\hline $\mathrm{MOD}<->$ INT & -0.088 & 0.049 & 1.088 & 22.143 & 0.000 \\
\hline FAM $<->$ LOY & 0.098 & 0.049 & 0.902 & 18.375 & 0.000 \\
\hline FAM $<->$ IND & 0.086 & 0.049 & 0.914 & 18.599 & 0.000 \\
\hline FAM $<->$ INT & -0.105 & 0.049 & 1.105 & 22.526 & 0.000 \\
\hline LOY $<->$ IND & 0.025 & 0.049 & 0.975 & 19.772 & 0.000 \\
\hline LOY $<->$ INT & -0.004 & 0.049 & 1.004 & 20.354 & 0.000 \\
\hline IND $<->$ INT & -0.49 & 0.043 & 1.490 & 34.652 & 0.000 \\
\hline
\end{tabular}

(Notes: REL: Reliability, SOP: Sophistication, MOD: Modern, FAM: Family-Oriented, LOY: Loyalty, IND: Independence, INT: Interdependence, $r$ : correlation, SE: Standard errors, CR: Critical ratio)

Table 2: Results of composite reliability and average variance extracted

\begin{tabular}{clcc}
\hline Item & Construct & $\begin{array}{c}\text { Composite reliability } \\
(\rho \mathbf{c})\end{array}$ & $\begin{array}{c}\text { Average variance extracted } \\
(\rho \mathbf{v c})\end{array}$ \\
1 & Reliability & 0.825 & 0.541 \\
2 & Sophistication & 0.826 & 0.616 \\
3 & Family-Oriented & 0.888 & 0.673 \\
4 & Modern & 0.896 & 0.682 \\
5 & Loyalty & 0.805 & 0.511 \\
6 & Interdependence & 0.972 & 0.880 \\
7 & Independence & 0.922 & 0.801 \\
\hline
\end{tabular}


Chi-square $=464.627, d f=303 ; p=.000 ; C M I N / d f=1.533$, $G F I=.920 ; T L I=.979 ; C F I=.976, R M S E A=.036 ;$ Hoelter $=300$

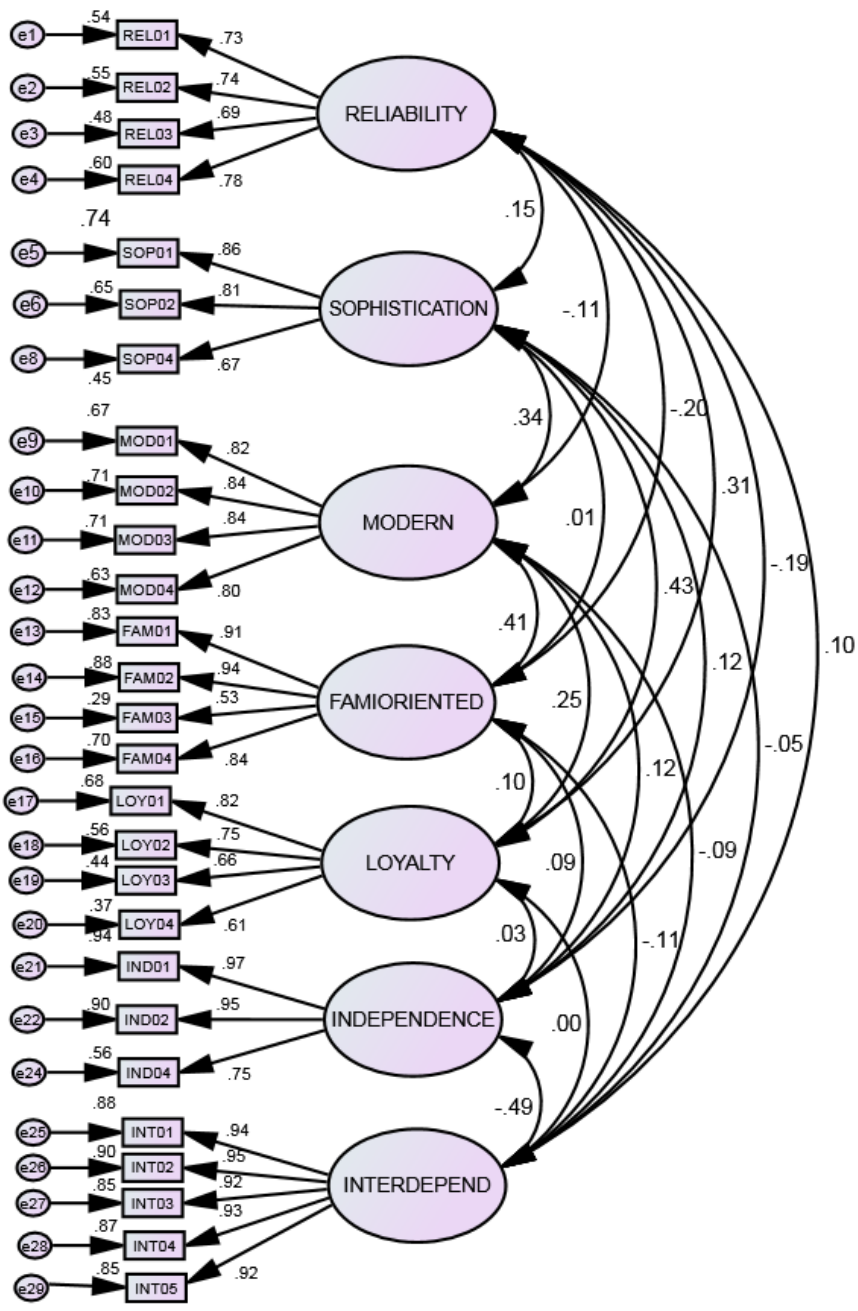

Figure 1: CFA results for full measurement model (Standardized estimates) 
Table 3: Estimates of structural equation coefficients (Independence)

\begin{tabular}{|c|c|c|c|c|c|}
\hline Hypothesis & Relationships & Estimate & S.E & C.R. & $\mathbf{P}$ \\
\hline H1a Supported & Loyalty $<-$ Reliability & .209 & .043 & 4.843 & $* * *$ \\
\hline H1b Supported & Loyalty $<-$ Sophistication & .284 & .053 & 5.314 & $* * *$ \\
\hline H1c Supported ${ }^{(*)}$ & Loyalty $<-$ Family-oriented & .074 & .039 & 1.881 & .060 \\
\hline H1d Supported ${ }^{(*)}$ & Loyalty $<-$ Modern & .063 & .039 & 1.634 & .100 \\
\hline $\mathrm{H} 2$ rejected & Loyalty $<-$ Independence & .010 & .032 & .311 & .755 \\
\hline H2a rejected & Loyalty $<-$ RELIND & -.001 & .040 & -.030 & .976 \\
\hline H2b Supported ${ }^{(*)}$ & Loyalty $<$ - SOPIND & -.059 & .035 & -1.710 & .087 \\
\hline $\mathrm{H} 2 \mathrm{c}$ rejected & Loyalty $<-$ FAMIND & .016 & .034 & .465 & .642 \\
\hline H2d Supported & Loyalty $<-$ MODIND & .078 & .032 & 2.432 & .015 \\
\hline
\end{tabular}

(Note: ${ }^{(*)}$ The hypotheses is supported at the significant level of $10 \%$ )

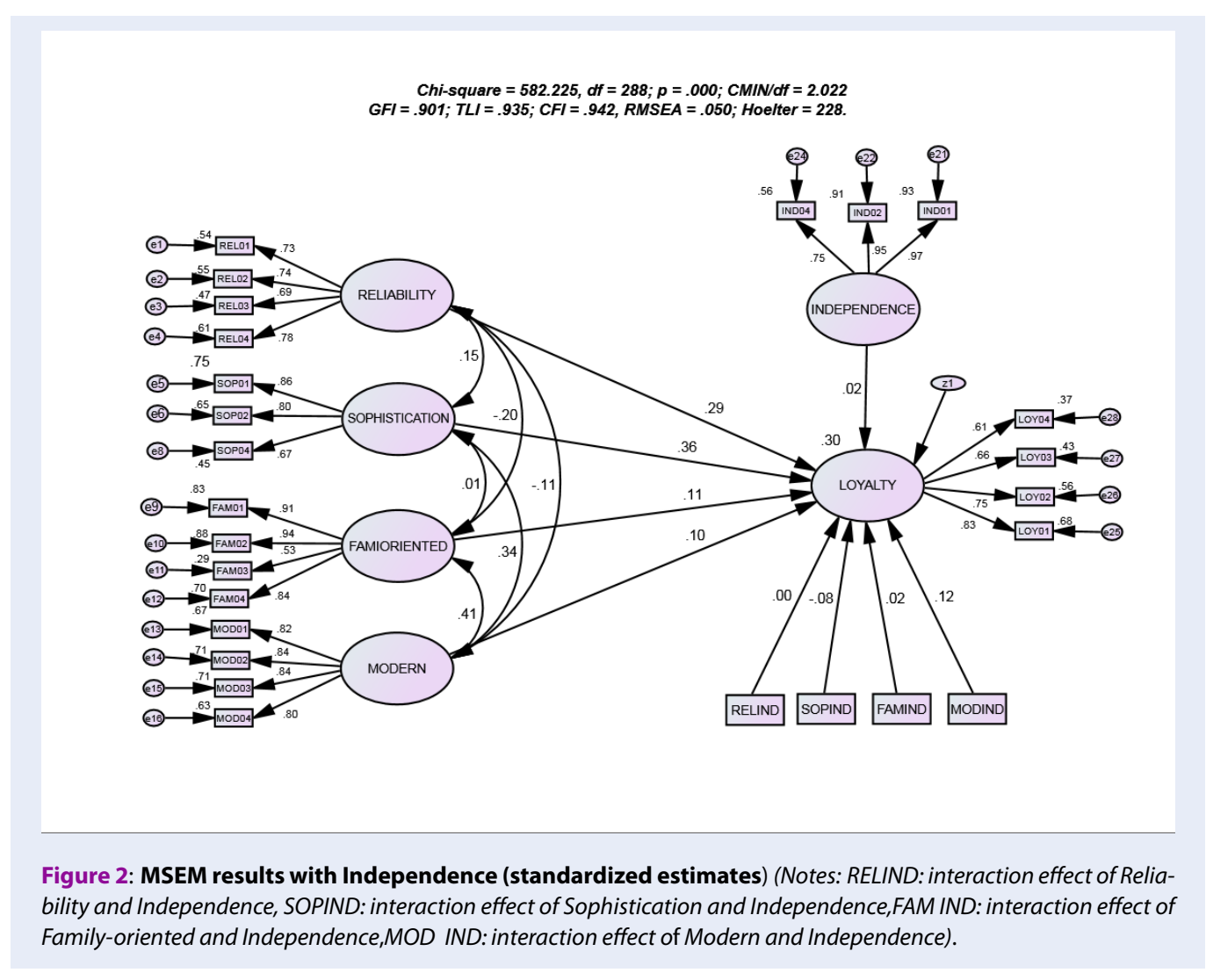


the interaction effect of Reliability with Interdependence were significant with the estimate equal to 0.051. It means that Interdependence decreases the degree of influence of Reliability on shoppers' loyalty (See Table 4). Besides, the relationship between the Independence and Interdependence with loyalty are not statistically significant that means that both personal cultural orientations are only pure moderators. Besides, effect size interaction coefficient $f^{2}$ was calculated to see how much influencing of the moderators ${ }^{59}$. The results indicated that the influencing degree of two moderators in the reseach was small effect with $f^{2} \leq 0.02$. However, McClelland \& Judd (1993) argued that the influencing degree with ratio of $1 \%$ was also regarded to have statistical significance in social science ${ }^{60}$.

Lastly, to evaluate the reliability of regression weight estimates among pairs of constructs in the model, bootstrap approach with $n=1,000$ was analyzed. The results revealed that the estimates by bootstrap with the bias from -0.001 to 0.004 , not too high, so the estimates was statistically reliable.

\section{RESULTS AND DISCUSSION}

The result of retail brand personality scale development indicated that the personality of supermarkets in Vietnam was constructed with four dimensions, slightly different from common five-dimension structure of product brand personality ${ }^{31}$, store personality $^{24}$ or department store personality ${ }^{26}$. This issue may be explained in terms of cultural differences. There are three same dimensions, namely Reliability, Sophistication and Modern and an absolutely different one, Family-oriented. Family-oriented dimension depicts clearly and lively the image of Vietnamese traditional women with four virtues in Confucianism. They are hard-working, good at housework, virtuous and the old - respectful (See Table 5).

Four dimensions of supermarket personality were found to be significantly related to shoppers' loyalty, in which Sophistication was the most influencing trait with the highest positive estimate. It argues that nowadays, consumers go shopping not only for the purpose of purchasing goods for functional use, but also for self-expression and showing their social status. Next, Reliability is also important for consumers since the supermarkets that can prove to be trustful with their products sold and their service delivered, will surely win consumers' loyalty. With the rapid technology growth, Modern is the characteristic that consumers are heading to. As a result, most of the supermarkets are equipped themselves with several modern utilities to serve shopping-goers better such as free wifi, relaxing music zone, resting benches and so on. Lastly, Family-oriented character is very suitable for supermarkets because most of shoppers are women who find themselves in this place.

$\mathrm{H} 2 \mathrm{~b}, \mathrm{~d}$ were supported, meaning that the shoppers with Independence culture appreciate more Sophistication and Modern to be loyal towards supermarkets. $\mathrm{H} 2 \mathrm{a}, \mathrm{c}$ were rejected to indicate that Family-oriented and Reliability characteristics are considered important factors on shoppers' loyalty towards supermarkets regardless the influence of independence culture. This result implies that high independence consumers with self-independent, self-confident often make purchasing decisions based their self-evaluation or experience.

Conversely, consumers with high interdependence culture underestimate the effect of retail brand personality on their loyalty ( $\mathrm{H} 3 \mathrm{~b}, \mathrm{c}, \mathrm{d}$ were rejected) but highly evaluate the impact of Reliability (H3a was supported ). This result can be explained as high interdependence consumers usually refer the norms and views of groups and then only select stores recommended by their groups. They do not like to express themselves, so the role of retail brand personality is too fade out to establish their loyalty.

Besides, Independence and Interdependence do not significantly direct impact on customer loyalty. This result is different from previous researches. This may be reasoned that in Vietnam, cultural orientations at individual levels are not showed strongly among consumers and loyalty depends much on physical store attributes instead of external environmental factors such as culture.

\section{CONCLUSIONS, IMPLICATIONS AND LIMITATIONS}

The results in this study have significantly contribut ed for existing marketing literature by reinforcing the knowledge generalization of the influencing degrees of each retail brand personality dimensions on customer loyalty in which the trait "Sophistication" and "Reliability" are strongest. Additionally, the exploration on moderating role of personal culture (independence and interdependence) on these relationships is a new point of this study. This is considered a first research in this regard in order to fill the knowledge gap about the impact of culture on retail branding and brand management.

MSEM method is still rare in research methodology. It will be also the source of reference for future research since MSEM method will correct some nonlinear and nonrandom measurement errors and give 


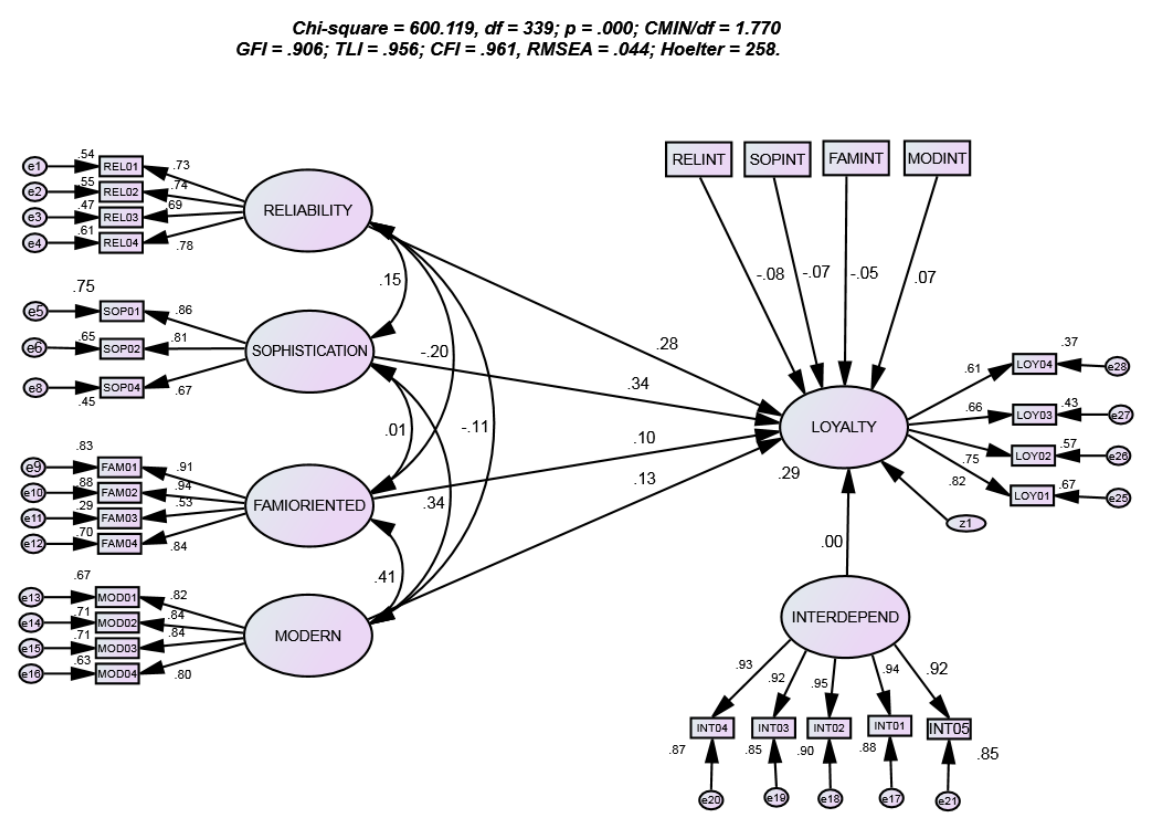

Figure 3: MSEM results with Interdependence (standardized estimates) (Notes: RELINT: interaction effect of Reliability and Interdependence, SOPINT: interaction effect of Sophistication and Interdependence, FAMINT: interaction effect of Family-oriented and Interdependence, MODINT: interaction effect of Modern and Interdependence)

Table 4: Estimates of structural equation coefficients (Interdependence)

\begin{tabular}{|c|c|c|c|c|c|}
\hline Hypothesis & Relationships & Estimate & S.E & C.R. & $\mathbf{P}$ \\
\hline H1a Supported & Loyalty $<-$ Reliability & .196 & .043 & 4.551 & $* * *$ \\
\hline H1b Supported & Loyalty $<-$ Sophistication & .266 & .053 & 5.029 & $* * *$ \\
\hline H1c Supported $\left.{ }^{*}\right)$ & Loyalty $<-$ Family-oriented & .064 & .039 & 1.635 & .100 \\
\hline H1d Supported & Loyalty $<-$ Modern & .082 & .039 & 2.091 & .037 \\
\hline H3 rejected & $\begin{array}{l}\text { Loyalty <- Interdepen- } \\
\text { dence }\end{array}$ & -.001 & .022 & -.026 & .979 \\
\hline H3a supported ${ }^{(*)}$ & Loyalty $<-$ RELIND & -.051 & .031 & -1.642 & .100 \\
\hline H3b rejected & Loyalty $<-$ SOPIND & -.040 & .027 & -1.486 & .137 \\
\hline $\mathrm{H} 3 \mathrm{c}$ rejected & Loyalty $<-$ FAMIND & -.028 & .028 & -1.003 & .316 \\
\hline H3d rejected & Loyalty $<-$ MODIND & .039 & .028 & 1.398 & .162 \\
\hline
\end{tabular}

(Note: ${ }^{(*)}$ The hypotheses is supported at the significant level of $\left.10 \%\right)$ 
Table 5: Comparison of brand personality

\begin{tabular}{|c|c|c|c|c|c|}
\hline \multicolumn{6}{|c|}{ Dimensions of brand personality } \\
\hline $\begin{array}{l}\text { Supermarket } \\
\text { personality }\end{array}$ & $\begin{array}{l}\text { Hoa \& } \\
\text { Thao } \\
(2017 \mathbf{a})^{27}\end{array}$ & Golberg $(\mathbf{1 9 9 0})^{61}$ & Aaker $(1997)^{31}$ & $\begin{array}{l}\text { D’Atous \& } \\
\text { Lévesque } \\
(\mathbf{2 0 0 3})^{24}\end{array}$ & Das et al $(2012 a)^{26}$ \\
\hline Reliability & Reliability & Conscientiousness & Competence & Genuineness & Authenticity \\
\hline Sophistication & Sophisticatior & & Sophistication & Sophistication & Sophistication \\
\hline $\begin{array}{l}\text { Family- } \\
\text { oriented }\end{array}$ & Economy & & & & Dependability \\
\hline \multirow[t]{6}{*}{ Modern } & & Extraversion & Excitement & & \\
\hline & Enthusiasm & Openness & & Enthusiasm & \\
\hline & & & Ruggedness & Solidity & \\
\hline & & Agreeableness & Sincerity & & Empathy \\
\hline & & Emotionality & & Unpleasantness & \\
\hline & & & & & Vibrancy \\
\hline
\end{tabular}

out more accurate results than multi-group analysis (MGA) when processing moderators as continuous/quantitative variables such as personal cultural orientations (Independence and Interdependence).

This study has several managerial implications based on research results. Firstly, the findings may help marketing management to re cognize that the symbolic value of retail brand plays a crucial role in consumer shopping behavior. Previously, retailers only concentrate on the functional attributes of supermarkets such as product variety, low price, convenience or promotion but neglect its symbolic benefits. Consequently, retail managers should develop an effective positioning strategy and re adjust integrated marketing and communication activities accordingly to improve the congruence between target shoppers' selfperception and retail brand personality. Secondly, the outcome of this research revealed that four personality dimensions were significantly correlated to shoppers' loyalty, as a result, retail managers must create these retail brand personalities for their supermarkets. Particularly, Sophistication is the most influencing characteristic to gain shoppers' loyalty and then, retailers should built an attractive and classy in-store environment together with professional staff to enhance retailer's Sophistication. Additionally, Reliability is also an important character for buying decisions and retailers must train quality control (QC) staffs to check input products strictly to avoid fake products with unclear origins present in their supermarkets or customer service staffs to keep promise with customers. Modern and Family-oriented should also be taken into consideration to develop and enhance for supermarkets to attract shoppers' loyalty because they reflect the image of Vietnamese women. Finally, personal culture is an issue that top management should always keep their eyes on. Front line staffs should be trained periodically to know how to cope with the shoppers from different cultures, for example high independence customers require more Sophistication and Modern with the expectation to express themselves whereas high interdependence customers underestimate the Reliability since their belief often depends on their in-group opinions.

The paper also has some limitations. Firstly, the paper was done for one retail format, general supermarkets. Thus, future research should be carried out for other formats such as shopping centers, department stores, fashion shops, beauty \& cosmetic shops, coffee shops, restaurants, etc. Service providers, where the symbolic image and self-expression are highly appreciated, should be recommended for testing. Secondly, the paper only looks at the impact of retail brand personality on loyalty without referring to other consequences (e.g. satisfaction, trust, store choice, purchase intention, brand equity and so on) and other factors contributing store personality. Therefore, future studies should take into consideration on these constructs and extend the model.

\section{ABBREVIATIONS}

AGFI: Adjusted good fit index

CFI: Comparative fit index

CFA: Confirmatory factor analysis 
EFA: Exploratory factor analysis

GFI: Good fit index

MGA: Multi-group analysis

MSEM: Moderated structural equation model

PLS: Partial least squares analysis

PCA: Principal component analysis

QC: Quality control

RMSEA: Root mean square error approximation

TLI: Tucker \& Lewis index

SMC: Squared multi correlations

SPSS: Statistical package for social sciences

\section{COMPETING INTERESTS}

The author declares that I have no conflicts of interest.

\section{AUTHORS' CONTRIBUTIONS}

The author has been in charged of the whole research paper.

\section{REFERENCES}

1. Phòng Thương Mại và Công nghiệp Việt Nam (VCCI). Báo cáo thị trường bán lẻ. Hà Nội: Tài liệu lưu hành nội bộ; 2018.

2. Nguyễn Lê Thái Hòa \& Hoàng Thị Phương Thảo. Tổng quan ngành bán lẻ Việt Nam: Mười năm nhìn lại và nhận diện các xu hướng mua sắm hiện nay. Hội thảo khoa học: Ban Kinh Tế Trung Ương; ngày 30-9-2016, Tp. Hồ Chí Minh; 2016.

3. Floor K. Branding a store: How to build successful retail brands in a changing marketplace. London: Kogan Page; 2006

4. Helgeson JG, Supphellen M. A conceptual and measurement comparison of self-congruity and brand personality. International Journal of Market Research. 2004;46(1):205-233.

5. Ailawadi KL, Keller KL. Understanding retail branding: Conceptual insights and research priorities. Journal of retailing. 2004;80(4):331-342.

6. Chun R, Davies G. The influence of corporate character on customers and employees: Exploring similarities and differences. Journal of the Academy of Marketing Science. 2006:34(2):139-146.

7. Zentes J, Dirk M, Hanna SK. Brand personality of retailers: An analysis of its applicability and its effect on store loyalty. The International review of retail. 2008;18(2):167-184.

8. Das G. Impacts of retail brand personality and self-congruity on store loyalty: The moderating role of gender. Journal of retailing and consumer services. 2014b;21(2):1-9.

9. Kim WJ, Lee F, Suh YG. Satisfaction and loyalty from shopping mall experience and brand personality. Services marketing quarterly. 2015;36(1):62-76.

10. Donvita R, Aiello G, Godey B, Pederzoli D, Wiedmann K, Hennings $\mathrm{N}$, et al. Are you like me? I will be attached to you. Empirical findings from an international research about consumer, brand and store personality congruence in luxury sector. In Proceedings of the academy of marketing science book series; 2016: . Springer Link; 2016.

11. Gouteron J. L'impact de la personnalite de la marque sur la relation marque-consommateur, application au marche' du pret - à-porter feminin. Rev Franc Mark. 2006;207(2/5):43-59.

12. Lombart $C$, Louis $D$. La personalite de l'enseigne un outil de marketing relationnel. Rev Manag Avenir. 2012b;51(1):15-41.

13. Lombart C, Louis D. Sources of retailer personality: Private brand perceptions. Journal of retailing and consumer services. 2016;28(2016):117-125.

14. Lombart C, Louis D. Consumer satisfaction and loyalty: Two main consequences of retailer personality. Journal of retailing and consumer services. 2012a;19(16):644-652.
15. Rahman O, Wong KK, Yu H. The effects of mall personality and fashion orientation on shopping value and mall patronage intension. Journal of retailing and consumer services. 2016;28(2016):155-164.

16. Rezaei $S$, Ali F, Amin M, Jayashree S. Online impulse buying of tourism products: The role of website personality, utilitarian and hedonic web browsing. Journal of hospital and tourism technology. 2016;7(1):60-83.

17. Merrilees B, Miller D. Superstore interactivity: A new selfservice paradigm of retail service? International journal of retail \& distribution management. 2001;29(8/9):379-389.

18. Wee TTT. Extending human personality to brands: The stability factor. Journal of brand management. 2004;11(4):317-330.

19. Lindquist JD. Meaning of Image. Journal of retailing. 19741975;50(4):29-34.

20. Martineau P. The personality of the retail store. Harvard Business Review. 1958;36(1):47-55

21. Moller J, Herm S. Shaping retail brand personality perceptions by bodily experiences. Journal of retailing. 2013;89(4):438446.

22. Brengman $M$, Willems $K$. Determinants of fashion store personality: A consumer perspective. Journal of product and brand management. 2009;18(5):346-355.

23. Das G. Store personality and consumer store choice behavior: An empirical examination. Marketing Intelligence \& Planning. 2014a;32(3):375-394.

24. D'Atous $A$, Levesque M. A scale for measuring store personality. Psychology of Marketing. 2003;20(5):455-469.

25. Willems K, Swinner G, Janssens W, Brengman M. Fashion store personality: scale development and relation to self-congruity theory. Journal of global fashion marketing. 2011;2(2):55-65.

26. Das G, Datta B, Guin KK. From brands in general to retail brands: A review and future agenda for brand personality measurement. The marketing review. 2012a;12(1):91-106.

27. Hoa NTL, Thao HTP. The impact of store personality on store loyalty: A study of specialty store chains in Vietnam. Journal of economic development. 2017a;24(1):119-134.

28. Fournier S. Consumers and their brands: Developing relationship theory in consumer research. Journal of consumer research. 1998;24(4):343-373.

29. Hoa NTL, Thao HTP. The antecedents and consequences of store personality: A study of specialty store chains in Vietnam. International review of business research papers. 2017b;13(1):88-103.

30. Straughan R, Alberts-Miller ND. An international investigation of cultural and demographic effects on domestic retail loyalty. International marketing review. 2001;18(5):521-541.

31. Aaker JL. Dimensions of brand personality. Journal of Marketing Research. 1997;34(3):347-356.

32. Ambroise $L$, Valette-Florence $P$. The brand personality metaphor and inter-product stability of a specific parameter. Research applied market. 2010;25(2):3-28.

33. Davies G, Chun R, Silva RD, Roper S. Corporate character scale to assess employee and customer views of organization reputation. Corporate reputation review. 2004;7(2):125-144.

34. Dick AS, Basu K. Customer loyalty: Toward and integrated conceptual framework. Journal of academy of marketing. 1994;22(2):99-113.

35. Pappu R, Quester P. A consumer-based method for retailer equity measurement: Results of an empirical study. Journal of retailing and consumer services. 2006;13(5):317-329.

36. Juyal SA. An empirical study on factors influencing store image, satisfaction and loyalty in department store [PhD Thesis]. South Africa: Faculty of management, Graphic Era University Dehradun. http://shodhganga.inflibnet.ac.in/bitstream/1060 3/5132/13/13_chapter\%206.pdf (accessed on 3 May 2018).

37. Dick AS, Basu K. Customer loyalty: Toward and integrated conceptual framework. Journal of Academy of marketing science. 1994:22(2):99-113.

38. Merrilees, B., \& Miller, D. Antecedents of brand personality in Australian retailing: An exploratory study. Proceedings of the ANZMAC conference, Melbourne, December 2, 2002 available 
at: http://smib.vuw.ac.nz:8081/www/ANZMAC2001/anzmac/ AUTHORS/pdfs/Merrilees1.pdf; 2002.

39. Lombart C, \& Louis D. A study of the impact pf corporate social responsibility and price image on retailer personality and consumers' reactions (satisfaction, trust and loyalty to the retailer. Journal of retailing and consumer services 2014.

40. Hofstede GH. Culture and organizations: software of mind. London: Mcgraw-Hill; 1991.

41. Seock YK, Lin C. Cultural influence on loyalty tendency and evaluation of retail store attributes. International Journal of retail \& distribution management. 2011;39(2):94-113.

42. Oyserman D, Coon HM, Kemmelmeier M. Rethinking individualism and collectivism: Evaluation of theoretical assumptions and meta-analyses. Psychological bulletin. 2002;128(1):3-72. Available from: 10.1037//0033-2909.128.1.3.

43. Sharma P. Measuring personal cultural orientations: Scale development and validation. Journal of the academic marketing science. 2010;38(787):787-806.

44. Furrer O, Liu SC, Sudharshan D. The relationship between culture and service quality perceptions: Basis for cross-cultural market segmentation and resource allocation. Journal of service research. 2000;2:355-371.

45. Watkins HS, Liu R. Collectivism, Individualism and In-group Membership: Implications for consumer complaining behaviors in multicultural contexts. Journal of international consumer marketing. 1996;8:1-28.

46. Lam D. Cultural influence on proneness to brand loyal. Journal of international consumer marketing. 2007;19(03):7-21.

47. Pappu R, Quester P. Does brand equity vary between department stores and clothing stores? Results of an empirical investigation. Journal of product \& brand measurement. 2008; 17(7):425-435.

48. Das G, Datta B, Guin KK. Impact of retailer personality on consumer - based retailer equity: An empirical study of retail brand. Asia pacific journal of marketing and logistics. 2012b;23(4):619-639.

49. Nunnally JC, Bernstein IH. Psychometric theory (3rd ed.). New York, NY: McGraw-Hill; 1994.
50. Hair JF, Balck WC, Babin BJ, Anderson RE, and Tatham RL. Multivariate data analysis, 6th Ed. New Delhi: Pearson Education; 2008.

51. Pappu R, Quester P. A consumer-based method for retailer equity measurement: Results of an empirical study. Journal of retailing and consumer services. 2006;13(5):317-329.

52. Jöreskog KG. Analyzing psychological data by structural analysis of covariance matrices. In: Krantz DH, Atkinson RC, Atkinson $\mathrm{RC}$, Luce $\mathrm{RD}$, Supes $\mathrm{P}$, editors. in contemporary developments in mathematical psychology. vol. 2; 1971. p. 1-56.

53. Sharma S, Durand RM, Gur-Arie O. Identification and analysis of moderator variables. Journal of marketing research. 1981;p. 291-300.

54. Cortina JM, Chen G, Dunlap WP. Testing interaction effects in LISREL: Examination and illustration of available procedures. Organizational research methods. 2001;4(4):324-360.

55. Bakker AB, Demerouti E. The crossover of work engagement between working couples: A closer look at the role of empathy. Journal of managerial psychology. 2009;24(3):220-236.

56. Ping RA. A parsimonious estimating technique for interaction and quadratic latent variables. Journal of marketing research. 1995;32(3):336-347.

57. Ping RA. Is there an example that shows all the steps in estimating a latent variable interaction/quadratic? from [on-line paper]. http://www.wright.edu/ robert.ping/yes.doc; 2007 a.

58. Ping RA. How should PRELIS or similar "preprocessor" software be used with LISREL, EQS, AMOS, etc. to create interactions/quadratics? [on-line paper]. http://home.att.net/ rping jr/PRELIS.doc; 2007b.

59. Cohen J. Statistical power analysis for the behavioral sciences (2nd ed.). Mahwah, N.J: Lawrence Erlbaum Associates; 1988.

60. Mcclelland GH, Judd CM. Statistical difficulties of detecting interactions and moderator effects. Psychological Bulletin. 1993;114(2):376-390.

61. Goldberg LR. An alternative "description of personality": The Big-Five factor structure. Journal of Personality and Social Psychology. 1990;59(6):1216-1229. 


\section{Vai trò điều tiết của văn hóa cá nhân trong mối quan hệ giữa nhân cách thương hiệu bán lẻ với lòng trung thành khách hàng: Trường hợp các siêu thị tại Việt Nam}

Nguyễn Lê Thái Hòa*

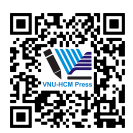

Use your smartphone to scan this QR code and download this article

Trường Đại học Công Nghệ Sài Gòn (STU)

Liên hệ

Nguyễn Lê Thái Hòa, Trường Đại học Công Nghệ Sài Gòn (STU)

Email: hoamai54@yahoo.com

Lịch sử

- Ngày nhận: 8/4/2019

- Ngày chấp nhận: 29/5/2019

- Ngày đăng: 31/12/2019

DOI : 10.32508/stdjelm.v3i4.574

\section{Check for updates}

\section{Bản quyền}

๑ ĐHQG Tp.HCM. Đây là bài báo công bố mở được phát hành theo các điều khoản của the Creative Commons Attribution 4.0 International license.

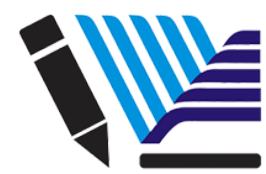

VNU-HCM Press

\section{TÓM TẮT}

Ngày nay, một trong những xu hướng phổ biến nhất trong nghiên cứu ngành bán lẻ là sự qui kết những tính cách con người vào trong thương hiệu. Thuật ngư "nhân cách thương hiệu bán lẻ" hay "nhân cách nhà bán lẻ" ra đời với nhiêu định nghĩa và thang đo khác nhau tùy thuộc vào những nền văn hóa khác nhau. Vi thế, mục tiêu của bài báo này nhằm (i) phát triển thang đo cho khái niệm nhân cách thương hiệu bán lẻ phù hợp với bối cảnh siêu thị tổng hợp - một mô hình bán lẻ phổ biến nhất ở Việt Nam, (ii) đo lường mức độ tác động của từng thành phần nhân cách thương hiệu bán lẻ lên lòng trung thành của khách mua sắm, và (iii) kiểm định tác động điều tiết của các xu hướng văn hóa cá nhân lên những mối quan hệ này. Thang đo khái niệm nhân cách thương hiệu bán lẻ được xây dựng thông qua hai giai đoạn: Tổng hợp và gạn lọc biến quan sát với dữ liệu thu thập được thông qua phương pháp lấy mẫu định mức 403 người đi mua sắm ở các siêu thị, sau đó đem đi phân tích bằng phương pháp SEM và MSEM (Mô hình cấu trúc tuyến tính điều tiết). Kết quả chỉ ra rằng nhân cách thương hiệu bán lẻ bao gồm bốn thành phần: Sự tin cậy, sự tinh tế, tính hiện đại và khuynh hướng gia đỉnh, và tất cả đêu có tác động ý nghĩa lên lòng trung thành khách hàng, trong đó sự tin cậy và sự tinh tế là hai thành phần tác động mạnh mẽ nhất. Thú vị hơn là vai trò điều tiết của các xu hướng văn hóa cá nhân cũng được xác định trong các mối quan hệ này. Cụ thể là, những người mua sắm có văn hóa độc lập cao đánh giá cao mối quan hệ giữa sự tinh tế và tính hiện đại với lòng trung thành trong khi người mua sắm mang văn hóa phụ thuộc cao chỉ ủng hộ tác động của tính tin cậy lên lòng trung thành. Tuy nhiên, cả hai xu hướng văn hóa này không có tác động trực tiếp và có ý nghĩa lên lòng trung thành. Những phát hiện của nghiên cứu này có thể giúp các nhà bán lẻ và nhà quản trị marketing tìm ra những giải pháp marketing hữu hiệu hơn bằng cách củng cố giá trị biểu tượng cho thương hiệu bán lẻ của họ và điều chỉnh các hoạt động truyền thông marketing tích hợp cho phù hợp hơn. Bài báo này có một đóng góp ý nghĩa trong việc khám phá vai trò điêuu tiết của các xu hướng văn hóa cá nhân trong mối quan hệ giữa các thành phần nhân cách thương hiệu bán lẻ với lòng trung thành của khách đi mua sắm bằng phương pháp phân tích mới - MSEM.

Từ khoá: Nhân cách thương hiệu, văn hóa, lòng trung thành, biến điều tiết, bán lẻ, Việt Nam
Trích dẫn bài báo này: Lê Thái Hòa N. Vai trò điều tiết của văn hóa cá nhân trong mối quan hệ giữa nhân cách thương hiệu bán lẻ với lòng trung thành khách hàng: Trường hợp các siêu thị tại Việt Nam. Sci. Tech. Dev. J. - Eco. Law Manag.; 3(4):328-342. 